\title{
Seasonal Variation in the Physico-chemical Characteristics of Surface Water in EtcheRiver, Niger Delta Area of Nigeria
}

\author{
${ }^{1}$ Oluyemi Ayorinde Akintoye, ${ }^{2}$ Comfort Nkazi Obi, ${ }^{3}$ Okon Asuquo Etim, \\ ${ }^{4}$ Tokunbo Olorundami , ${ }^{5}$ Sammy Uka Ukata, ${ }^{6}$ Edet Ubong Harrison \\ 1,2,3,4,5,6 Department of Geography and Environmental Science, University of Calabar, Nigeria
}

\begin{abstract}
This study examined the seasonal variation in the physico-chemical characteristics of surface water in Etche River in Rivers State, Nigeria. The study area is a vast theatre for multiple petroleum development and cottage industries activity. Water samples were collected during the dry and wet seasons, from six sampling points, two samples along the river course. Grab (Catch) water sampling method was used in collection of water samples into PVC and Biological Oxygen Demand (BOD) bottles, during the two different seasons. The water samples were well labeled and stored at $4^{O} \mathrm{C}$. Water Temperature $(T), p H$ and Electrical Conductivity $(E C)$ were measured by mercury bulb thermometer, $\mathrm{pH}$ meter and Conductivity-total dissolved solids (TDS) Meter, respectively. Dissolved Oxygen (DO), Total Alkalinity (TA) and free Carbon Dioxide $\left(\mathrm{CO}_{2}\right)$ were analyzed by standard methods (Eaton and Franson, 2005). Differences exist in observed physico-chemical properties of water samples collected during the two seasons. For instance, during the wet season, the level of magnesium, Calcium, and $\mathrm{pH}$ were $72.22(\mathrm{mg} / \mathrm{l}), 297.3(\mathrm{mg} / \mathrm{l})$ and 5.07 respectively, while values for dry season were $63.19(\mathrm{mg} / \mathrm{l}), 260.1(\mathrm{mg} / \mathrm{l})$ and 6.11 respectively. Value for TDS in both seasons samples were relatively higher than the Federal Environmental Protection Agency (FEPA) stipulated limits. Copper concentration was found to be between 0.09 and $0.06 \mathrm{mg} / \mathrm{l}$. The study revealed the disposal of industrial, commercial and domestic waste into Etche River. Recommendations, preferred include, the need to control point source and non-point source contamination of the Etche River
\end{abstract}

Key Words: Physico-Chemical Parameters, seasonal variation, surface water, pollutants

\section{Introduction}

Several empirical and theoretical literatures on the physic-chemical and bacteriological aspects of natural and drinking water quality exists (Oluwande etal (1980), Esreyet al (1985) ,Sharma et al(1995), Esrey (1996), Smith et al (2000), Dwivedi. and Pandey (2002), WHO (2002, 2004a and 2004b), NWP (2002) Ashbolt (2004), Begum et al (2004),Turgeon et al(2004), Eaton and Franson (2005), Chowdhury et al(2006), Ayse et al (2008), Bhuiyan and Gupta (2007), Naik and Wanganeo (2008), Schmidt and Esa (2008), Aina (1996) . However, studies by , Oluwande (1980), Amadiet al (1989),Imoke (2012), Udom et al, Ugbaja and Edet (2004), Igbokwe (2005) Badmus (2008) and Rimonson (2008), Adejuwon (2012) among many others, makes graphic references to local water related problems in Nigeria.

Among the numerous natural resources on earth, water is one of the most essentialfor life support. Water is required for domestic, industrial and agricultural purposes, in both rural and urban areas, the sources of which include:rivers, streams, ponds and wells (Adejuwon and Adelakun, 2012). Rivers in particular are waterways of strategic importance across the world, providing main water resources for multiple uses.

The choice of Etche River for this study is justified by the fact that the communities through which it passes, are hosts to numerous crude oil exploration and exploitation activities. Water bodies like the Etche River are constantly used as receptacles for untreated water or poorly treated effluents which accrued from industrial activities. This may render the water body unsuitable for both primary and secondary usage. One of the most critical crises in Etche communities is the lack of adequate portable water. Generally, in Rivers state, one of the major problems is getting portable water, because of environmental pollution. The plight of Etche communities of Rivers state, due to the consequences of resources exploration and exploitation activities on the physical and cultural environment, as well as the way forward, have been adequately documented byboth Naagbanton(1999) and Nwokogba (2013).

In particular Nwokogba (2013) stated that the major fresh water rivers in the area include Otamirioche, Ogueche, and Imo. He noted that, farming is a major occupation of Etche people. This explains the popular reference to Etche as the "bread basket" of Rivers State. However, the discovery and exploitation of the vastly available Crude Oil and Natural gas resources, has culminated in negative consequences in the environment, especially in such areas as Agbada, Imo River, Nkali, Otamiri, Oyigbo North, and Umuechem. The presence of networks of pipelines, flow-stations and gas processing plants, now impacts the aesthetics of the area. $\mathrm{He}$ submitted that Etche, by the most pessimistic estimate, is the third largest producer of crude oil and gas in the 
state. He pointed out that Oil and gas activities produce various negative and inescapable effects on human environment. He decried, a situation where, Etche has borne significant brunt of the consequences of the impact crude oil spills and pollution, which have resulted in severe impact on arable and dwelling lands, as well as the water table; fresh water river pollution; gas flaring resulting in acid rain and diminishing crop yields; restiveness and violent confrontations; insecurities; health hazards. He pointed out that, specifically, Etche has had eight known and documented major oil spills, which do not include numerous effluent discharges into the rivers.

In developing countries, as industrial geography evolve, in the present decade, it must as it is done in this study, focus more on the socio-economic, bio-physical and health consequences of industrialization , and avoid focusing solely on the traditional theories of economics of land rent and locations yielding maximum profit . Location of industries are largely politicized, in Africa with the least concern about the immediate and long time consequences on the host communities

Against this background, the need for a study of the effect of anthropogenic activities on the aquatic environment in rural communities like those in Etche, which are hosts to widespread agricultural activities, large scale industrial and petroleum development activities cannot be overemphasized. A study like this has also becomes necessary and in fact, more urgently needed, given the increasing petroleum industry activities related myriad of conflicts, devastating poverty, massive crude oil theft and spillage, as well as high level of pollution.

\section{Study Area}

Etche River is in Etche Local Government Area (LGA) of Rivers state, which is within the conflict riddled oil rich Niger Delta Area of Nigeria. Etche is located between Longitude $6^{0} 55^{\prime} 00^{\prime \prime}$ and $7^{0} 08^{\prime} 15^{\prime \prime}$ East and Latitude $4^{0} 53$ ' 30 " and $5^{\circ} 12^{\prime} 15^{\prime \prime}$ North. Etche River dissects the Local Government into parts and is one of the important sources of the Nigerian petroleum resources. Etche communities are also drained by such Rivers as Otamirioche, Ogueche, and Imo.

The study area is bounded in the North by Ohaji/Egbema and Ngor Ogbala LGAs of Imo state, to the east by Omuma LGA of Rivers state; to the south by Oyigbo and Obio/Agbor LGA and to the west by Ikwerre LGA. The Etche area contains two local government areas of Rivers State, which include Etche and Omuma local government areas. Nwokogba (2013) points out that Etche's land mass totals about 97,500 hectares (376.5 square meters) and the total population is estimated to be at least 600,000 persons.

Table 1, presents some communities within the study area, while Figure 1: shows Etche River and surrounding communities.

Table 1. Some communities within the study Area

\begin{tabular}{|l|l|l|}
\hline S/N & Community & Villages \\
\hline 1 & Chokota & $\begin{array}{l}\text { Igbo, Ikwerengwo, Umueze, Umuechem, Umusalem, Eguri, Okoroagu } \\
\text { Umuaria }\end{array}$ \\
\hline 2 & Nchokoche & Umuanyagu, Chokoche, Odogwa, Umuakuru, Edegelem \\
\hline 3 & Okomoko & Amaato, Ulakwo, Odufo \\
\hline
\end{tabular}

Source : Researcher's Fieldwork (2012)

\section{Methods}

Six sampling stations along Etche River course were selected for the study. Systematic random sampling technique was adopted for the collection of the surface water samples at about regular distances of one kilometer apart in each river courses ,such as the upper, middle and the lower sections of the river. A Global Positioning system (GPS) handset was used to locate the points and find same in the next season.

Water samples were collected in two different seasons: May for dry season and October, for rainy season, during morning hours, between 8.30 a.m. to 11.30a.m. in one litersterile

Plastic bottles and instantly transferred to the laboratory for analysis. Water samples were collected during the dry and wet seasons from six sampling points, two samples along each of the three river courses (upper, middle and lower courses).

Water samples were collected in PVC and Biological Oxygen Demand (BOD) bottles, from the two different sites. Collected water samples were all well labeled and stored at $4^{\mathrm{O}} \mathrm{C}$. Notably Water Temperature (T), pH and Electrical Conductivity (EC) were measured by mercury bulb thermometer, $\mathrm{pH}$ meter and Conductivity-total dissolved solids (TDS) Meter, respectively. Dissolved Oxygen (DO), Total Alkalinity (TA) and free Carbon Dioxide (CO2) were analyzed by standard methods. The analyses were based on APHA (2005)and compared with the standard values of Federal Environmental Protection Agency (FEPA) now NESREA.All samples were clearly labelled by site number of sample. Samples were refrigerated between 1- 
$4^{\mathrm{O}} \mathrm{C}$ (not allowed to freeze) and analyzed, within 6 days of collection. However, in-situ analysis were carried out for $\mathrm{pH}$, Dissolved oxygen (DO) and Electricity conductivity (EC) .

\section{Results}

\subsection{Physico-Chemical Parameters of Water Samples in Etche River}

The comprehensive analysis results for all the six surface water samples taken during each season, have been summarised in averages as presented in tables 2 (physical parameters) and 3 (Chemical parameters) Thus, the average values derived from the water analysis, were compared with allowed limits stipulated by Federal Environmental Protection Agency ( FEPA,1998).

Based on the results of the water analysis, the average values of $\mathrm{pH}$ of the water samples for both seasons are within the WHO standards range of $6.50-8.50$. The average $\mathrm{pH}$ for all the three samples during the wet season is 5.67, while that of the dry season is 6.11. The level of $\mathrm{pH}$ was higher in the dry season, than in the wet season. According to Government of Western Australia (2009:16) "the pH of a solution is the concentration of hydrogen ions, expressed as a negative logarithm." It indicates the acidity or alkalinity of such a particular solution, such as water. An aquatic body or sample with a $\mathrm{pH}$ of 7 . is neutral, while a lower $\mathrm{pH}$ low level signify

Figure 1: The study area-Etche River and the communities

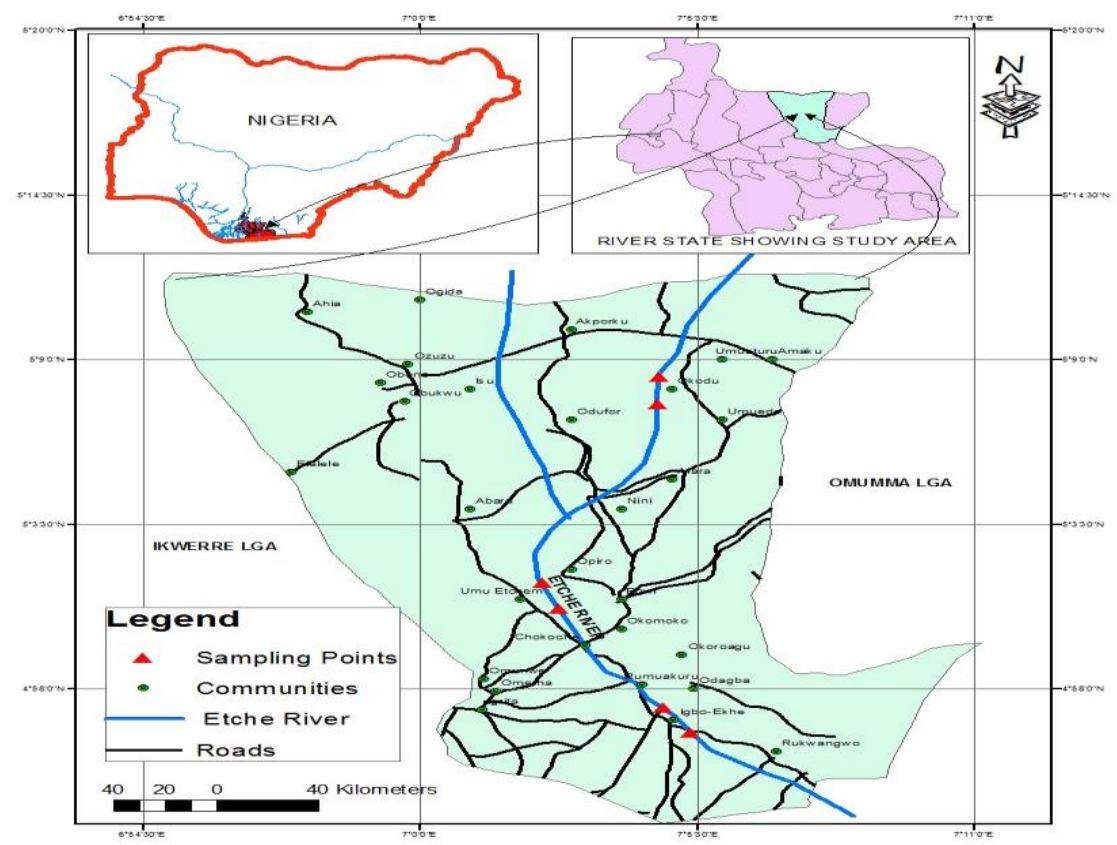

(Source: Produced by Researchers, 2013)

increasing acidity. Also a pH levels higher than 7 reveals an increasingly level of alkalinity in the solutions. Notably , pH level has implication on other potential toxicants, such as the bio-availability of heavy metals and so on.

The average level of Electrical conductivity (EC) was high in the wet season, but low in the dry season with values of $12.30 \mathrm{~ms} / \mathrm{cm}$ and $10.77 \mathrm{~ms} / \mathrm{cm}$ respectively. Interestingly, Government of Western Australia (2009: 14) also explained that the EC test helps to measure the ability of water to conduct an electric current. This largely depends on the number of ions or charged particles available in within the water.

Table 2 Physical parameters of water samples in comparison with the FEPA standard.

\begin{tabular}{|l|l|l|l|l|}
\hline S/N & Parameters & Wet season & Dry season & FEPA Limits \\
\hline 1 & Electricity conductivity (ms/cm) & 12.30 & 10.77 & N/A \\
\hline 2 & Total Dissolved solid (TDS) (mg/L) & 61.54 & 53.84 & $35-50$ \\
\hline 3 & Odour & Fouling & Fouling & N/A \\
\hline 4 & Total Suspended Solid (TSS)(mg/L) & 31.0 & 29 & 30 \\
\hline 5 & $\mathrm{pH}$ & 5.67 & 6.11 & $6-9$ \\
\hline 6 & Turbidity (FTU) & 81 & 28 & $<10$ \\
\hline
\end{tabular}

FTU= Formuzin Turbidity Units; N/A=Not available

Source: FEPA (1998) and Researchers' Fieldwork (2013) 


\section{Chemical Parameters of Water Samples and FEPA Limits}

\begin{tabular}{|l|l|l|l|l|}
\hline S/N & Parameters & Wet season & Dry season & FEPA limits \\
\hline 1 & Calcium(mg/L) & 297.3 & 260.1 & 200 \\
\hline 2 & Magnesium (mg/L) & 71.22 & 63.19 & 200 \\
\hline 3 & Sulphate(mg/L) & 619.2 & 541.8 & 500 \\
\hline 4 & Nitrate(mg/L) & 4.012 & 0.688 & 10 \\
\hline 5 & Phosphate(mg/L) & 0.019 & 0.016 & 5 \\
\hline 6 & Copper & 0.09 & 0.06 & 1.5 \\
\hline
\end{tabular}

Source: FEPA (1998)and Researchers' Fieldwork (2013)

Where low values are observed, it shows that the water body is of high-quality, and there is lownutrient level present in such water. The reverse is the case with higher values. This is a common scenario, in areas where fertilizers has been used for agriculture, and a state of eutrophication has occurred..But a test of electrical conductivity, usually lacks the ability to indicate the specific ionic composition and concentrations, existing within the water body

The average total dissolved solids(TDS) value for the analysis, revealed a value of $61.54 \mathrm{mg} / \mathrm{I}$ for wet season and a lower value of $53.84 \mathrm{mg} / \mathrm{l}$ for the dry season. This gives a mean value of $57.69 \mathrm{mg} / \mathrm{I}$ for both seasons . Total suspended solids (TSS) are defined as the portion of total solids in a watersample retained by a glass fibre $(\mathrm{GF} / \mathrm{C})$ filter of pore size $>2 \mu \mathrm{m}$.

The average river temperature values were almost the same at both seasons, and rangesbetween $26.7^{\circ} \mathrm{C}$ and $26 .{ }^{\circ} \mathrm{C}$, respectively. These values fall below the FEPA stipulated limits of $35^{\circ} \mathrm{C}-40^{\circ} \mathrm{C}$ by FEPA.The implication of temperature range is explained by Western Australia Government (2009). The institution noted that water temperature regulates various biochemical reaction rates that influence water quality, through the dynamics of fluctuating solar radiation, back radiation, evaporative cooling and heat conduction, thermal dischargers, such as occur in the cooling of water from power plants, tributary inflows and groundwater discharges.

The average value for the level of total suspended solid (TSS) was high in the wet season and low in the dry season. The average values for the total suspended solid (TSS) are $31.0 \mathrm{mg} / \mathrm{l}$ and $29 \mathrm{mg} / \mathrm{l}$ for the wet and dry seasons respectively. This shows that the TSS for the wet season water sample is above FEPA limit of 30 $\mathrm{mg} / \mathrm{l}$, while that of dry season is below FEPA's standard.

Turbidity was low in the dry season with a value of 28FTM and high in the wt season with 81/FTM. The turbidity values recorded for both samples were higher than the FEPA recommended limit of <10/FTM for drinking water. This shows that the river contains a lot of pollutants. High turbidity levels lead to high level of deposition and silt problem in the water were the waste is discharge. The wet and dry seasons water samples were found to have noticeable odour. This suggests the presence of biodegradable materials, bacteria and decomposition processes going on

The average values of the calcium content of the water samples was high in the wet season, having a value of $297.3 \mathrm{mg} / \mathrm{I}$, whereas the dry season showed a calcium value of $260.1 \mathrm{mg} / \mathrm{I}$. Similarly, the magnesium content, was observed to be high in the wet season and lower in the dry season. The sulphate content was high in the wet season with a value of $619.2 \mathrm{mg} / \mathrm{me}$ and low in the dry season, with a value of $541 \mathrm{mg} / \mathrm{I}$. These may be explained by the fact that agricultural activities necessitating the use of fertilizers in a raining period, can result in washing away of nutrients into the rivers, from a widespread agricultural area, and thus resulting in the increase in level of certain chemical elements. During raining season, it could have been logical to assume that high rainfall volume will result, in considerable dilution, resulting in low concentration of chemical elements

Nitrate concentration was almost the same across the sampling stations with values of $4.012 \mathrm{mg} / \mathrm{I}$ in the wet season and $4.688 \mathrm{mg} / \mathrm{I}$ in the dry season. Phosphate for the two seasons, were almost similar with recorded values of $0.019 \mathrm{mg} / \mathrm{I}$ in the wet season and $0.016 \mathrm{mg} / \mathrm{I}$ in the dry season. Water samples from the two seasons showed copper had a value of $0.09 \mathrm{mg} / \mathrm{I}$ in the wet season and $0.06 \mathrm{mg} / \mathrm{I}$ in the dry season.

\section{Discussion}

The presence in high concentrations of some chemical elements is as a result of the presence of pollutants. The water body is at the receiving end of many industrial and household chemical and organic wastes , thereby leading to a concentration of observed pollutants. The study by Sahni and Yadav, (2012) observed that the pollutant receiving water body arereservoirs of pollutant which is most unsuitable for aquatic biota and for aquaculture or any other purpose.

Uncontrolled effluents by oil companies and domestic and agricultural wastes from the communities discharged into the rivers in the areahave displayed strong potentials that has resulted in eutrophication, for example in Etche River, with gradually wide- spreading algae population, as well as high concentrations of some parameters as evidenced by substantial increase in calcium, magnesium and sulphates.Total Dissolved Solid (TSD) of the water samples of both seasons were quite high when compared with FEPA standard of 
1998.The high TSD may be attributed to the erosion from the landward site. The TSD was higher in the rainy season than the dry season.

The calcium content of the samples which clearly exceeded FEPA's specified limit of $200 \mathrm{mgl}^{-1}$. The concentrations of parameters above the expected limits directly as well as indirectly influences many abiotic and biotic components of aquatic ecosystem. Several studies have corroborated this assertion just as the existence of algae bloom in Etche river. The parameters such as Dissolve oxygen, temperature, BOD among others reflects to the dynamics of the living organisms such as metabolic and physiological behavior of aquatic ecosystem (Singh and Mathur,2005).This has been confirmed by Godhantaram and Uye, 2003 that Water asthe most precious resource on earth also play a predominant role in distribution of organisms. Fresh water contains various micro-organisms. While Raibole and Singh (2011) opined that the quality of water through parameters (Physico-Chemical) affects the species composition, their abundance and productivity of water.

Some organisms can survive in a wide range of conditions and some are more tolerant to pollution while others are very sensitive to changes in conditions and intolerant to pollution. The concentration of chemical parameters in Etche River will not only affect the quality for domestic use but also other living biota as confirmed from other researchers.

\section{Conclusion}

From the analysis, it has been seen that there is a seasonal variation in the quality of water in respect to the physical and chemical parameters. Conductivity, TDS, TSS, were slightly higher during the wet season, while parameters such as Turbidity, calcium, magnesium and sulphates were significantly higher during the wet season. Moreover, some of the physical parameters such as TDS, turbidity, TSS and electrical conductivity were quite above the expected FEPA limits, which is the standard for the country. Chemical parameters that exceeded FEPA limits include calcium, magnesium and sulphates. This indicates that the concentration in the wet season may be due to run-off from the land to the river and most of the pollutants are directly dumped into the water in the rainy season.

\section{Recommendations}

Therefore the following recommendations have been made:

(i) Due to the importance of the river to the inhabitants of the study area , studies focused on the morphoadaptic characteristics of the river and river ecology studies are advocated to guarantee data availability for proper planning and management of the catchment

(ii) Anthropogenic influences within and around the river should be monitored and controlled. The discharge of industrial effluents and other toxic substances, into the Etche River should be prohibited

(iii) Periodic physico-chemical studies of the Etche River should be carried out periodically, by concerned agencies

(iv) Waste disposal cans, dumpsters and dumpsites, should be provided or purchased by households. Dumpers of solid and liquid wastes of domestic, commercial and industrial origins should be penalised.

(v) Alternative sources of household water should be provided. Given the high level of poverty in the area, free public sources of water would be a better option

(vi) The Integrated River Management Approach should be adopted in the utilization of the Etche River.

\section{References}

[1]. Adejuwon J. O. and Adelakun M. A (2012) Physiochemical and bacteriological analysis of surface water in Ewekoro Local Government Area of Ogun State, Nigeria: Case study of Lala, Yobo and Agodo Rivers. International Journal of Water Resources and Environmental Engineering. 4(3), 66-72,

[2]. Aina, E. O. A.; Adedipe, N. O., (1996). Water Quality Monitoring and Environmental Status in Nigeria. FEPA Monograph 6, FEPA, Abuja, Nigeria, 239.

[3]. Amadi , P. A ., Ofoegbu , C.O and Monison, T (1989) Hydrogeochemical Assessment of Groundwater Quality in Parts of the Niger Delta, Nigeria, Environmental geology , pp 44-46

[4]. Anukool, S.; Shivani, S. (2011). Assessment of Physico-Chemical Properties and Sewage Pollution Indicator Bacteria in Surface Water ofRiver Gomti in Uttar Pradesh. International Journal of Environmental Sciences 2 (1) 2

[5]. APHA (2005) : Standard Methods for the Examination ofWater and Waste Water.

[6]. Ashbolt, N.J., 2004. Microbial Contamination of Drinking Water and Disease Outcomes in Developing Regions. Toxicology, 198: 229-238. DOI: 10.1016/j.tox.2004.01.030

[7]. Ayse, E., F.O. Topac., N. Ozengin, A. Teksoy and S. Kurtoglu ., (2008). Evaluation of Physical, Chemical and Microbiological Properties of Lake Uluabat, Turkey. J. Environ. Biol., 29: 205-210. PMID: 18831376

[8]. Badmus., B.S (2008) "Leachate Contamination Effect on Groundwater Exploration" In Imoke D. E (2012) The Effect of Aquifer Characteristics on Groundwater Yield and Quality in Calabar South, Nigeria , A PhD Dissertation , Department of Geography and Regional Planning, University of Calabar, Nigeria

[9]. Badmus , B. S ., Odewande, A.A Ojelabi , E. A and Oyedale, T (2008) "Ground Water in Nigeria - Millennium Experience , Distribution, Practice, Problems and Solutions" In Imoke D. E. (2012) The Effect of Aquifer Characteristics on Groundwater Yield and Quality in Calabar South , Nigeria , A PhD Dissertation, Department of Geography and regional Planning, University of Calabar, Nigeria 
[10]. Begum, J., K. Ahmed, K.N. Bora and A. Hussain, (2004).Coliform bacteria in different sources of Drinking Water During Different Seasons. Poll. Res., 23: 607-609.

[11]. Bhuiyan, J.R. and S. Gupta, (2007). A Comparative Hydrobiological Study of a Few Ponds of Barak Valley, Assam and their Role as Sustainable Water Resources. Journal of Environmental. Biology., 28: 799-802.

[12]. Chapman, D., (1996). Water Quality Assessments: A Guide to the Use of Biota, Sediments and Water in Environmental Monitoring $2^{\text {nd. }}$ Ed. , UNESCO, World Health Organization, United Nations Environment Programme, London.

[13]. Chowdhury, M.A.I., M.T. Uddin, M.F. Ahmed, M.A. Ali and S.M.A. Rasul ., (2006). Collapse of Socio-economic Base of Bangladesh by Arsenic Contamination in Ground Water. Journal of Biological Sciences., 9: 1617-1627

[14]. Dwivedi, B.K. and G.C. Pandey, (2002). Physico-chemical Factors and Algal Diversity of Two Ponds (Girija kund and Maqubara pond), Faizabad, India. Poll Res., 21: 361-370.

[15]. Eaton, A.D. and M.A.H. Franson,(2005). Standard Methods for the Examination of Water and Wastewater. 1st Edn., American Public Health Association, Washington, DC., ISBN-10: 0875530478, pp: 1200.

[16]. Ekop, O. B. (2003) Pollution assessment to Public Water Supply in Calabar Nigeria in Adinna E.N; Ekop O.B. and Attah V.I. (ed) Environmental Pollution and Management in the Tropics. Published and Printed by SNAAP Press Ltd Enugu Nigeria.

[17]. Environmental Rights Action (1999)Toxic War Against Umuakuru-Igbo People Era Field Report Number 21 , A letter from Patrick Naagbanton , Dispatched to Umuakuru-Igbo, Etche RGers State , http://www.essentialaction.org/shell/era/field21.html (Browsed: 9-8-2013)

[18]. Esrey, S.A., (1996). Water, Waste and Wellbeing. A multicountry study. American. Journal. of Epidemiology, 3: 608

[19]. Esrey, S.A., R.G. Feacham and J.M. Hughes, (1985). Interventions for the Control of Diarrhoeal Diseases among Young Children. Improving Water Supplies and Excreta Disposal Facilities. Bulletin of World Health Organisation ., 63: 757-772

[20]. Federal Environmental Protection Agency (FEPA, 1998). Allowable limits for portable water. Lagos, Nigeria.

[21]. Gupta, A., (2004). Drinking Water Quality in Barak Valley.Proceedings of the 2nd APHW Conference. Asia Pacific Association of Hydrology and Water Resources, Japan. pp: 621-627

[22]. Gupta, S., K. Buragohain and J.R. Bhuiyan, (2008). Importance of Ponds in Integrated Water Resource Management in Barak Valley. Poll. Res., 27: 587-590.

[23]. European Water Framework Directive-WFD ( 2000),Integrated Framework for Improving, Protection and Management of Europe's Water Resources and Aquatic Environment.

[24]. George, B(2003). Sustainable Water Resource Management ; Technical University of Lasi, Faculty of Industrial Chemistry Mangewn Bd, 700050 Lasi, Romania.

[25]. Godhantaram,N.And Uye, A.(2003) Geographical and Seasonal Variations in Taxonomic Composition, Abudance and Biomass of Microzooplankton Across a Brackish - Water Lagoonal System of Japan. Journal of Plankton Research. 25: 465-482.

[26]. Government of Western Australia (2009) Surface Water Sampling Methods and Analysis -

[27]. Technical Appendices, Standard Operating Procedures for Water Sampling - Methods and Analysis, January 2009 , Berth , Western, Australia, http://www.water.wa.gov.au /PublicationStore /first/ 87152.pdf (Retrieved : 5/12/2013)

[28]. Igbokwe, M. U (2005) "Seasonal Variation of physic-chemical Characteristics in Water Resources Quality in western Niger Delta region" " In Imoke D E (2012) The Effect of Aquifer Characteristics on Groundwater Yield and Quality in Calabar South , Nigeria , A PhD Dissertation, Department of Geography and Regional Planning, University of Calabar , Nigeria

[29]. Kamal et al (2007). Physico-Chemical Properties of Water of Mouri River, Khuema, Bangladesh; World Journal of \fish and Marine Sciences 2, IDOSI Publications, 2010.

[30]. Khitoliya R.K (2004) Environmental pollution, Management and Controlfor Sustainable Development, S. Chand and Company , New Delhi, India

[31]. Mmom, P.C. and Chukwu-Okeah, G.O. (2011); Factors and Processes of Coastal Zone Development in Nigeria: A Review, Research Journal of Environmental and Earth Sciences 3(6): 625-632, 2011

[32]. Mabogunje, A. L. (1965) "Water Resources and Economic Development in Nigeria In Brockensha D.W. (ed) Ecology and Economic Development in Africa. University of califonia Press. P. 149

[33]. Naagbanton ,.P (1999)Toxic War Against Umuakuru-Igbo People Era, Field Report Number 21 , A letter from Patrick Naagbanton, Dispatched to Umuakuru-Igbo, Etche LGA, Environmental Rights Action, Rivers State ,http://www.essentialaction .org/shell/era/field21.html (Browsed: 9-8-2013)

[34]. Naik, A.A. and A. Wanganeo,( 2008). Seasonal variation of heavy metals in surface water Samples of Upper Basin ofBhoj Wetlands, Bhopal. PollutionResearch. 27: 649-653.

[35]. Nwokogba , A (2013 ) Etche and NDDC: A Consideration , http://theneighbourhood.com.ng/opinionnew/157-etche-and-nddc-aconsideration.html (Browsed: 9-8-2013)

[36]. NWP, (2002). Ministry of water resources. Govt. of India, New Delhi.

[37]. Ogbaja., A.N. and Edet., A.E. (2004) Groundwater Pollution Near Shallow Waste Dumps in Southern Calabar, South- Eastern Nigeria "In Imoke D. E., (2012) The Effect of Aquifer Characteristics on Groundwater Yield and Quality in Calabar South , Nigeria , A Ph.D Dissertation, Department of Geography and Regional Planning, University of Calabar, Nigeria

[38]. Oluwande, P.A., M.K. Sridhar, A.O. Bammeke and A.O. Okubadejo, (1980). Pollution levels in Some Nigerian Rivers. Water Resources ., 17: 957-963. DOI:10.1016/0043-1354(83)90035-0

[39]. Patra A, Gocin G. (2010); Seasonal Variations in Physio-chemical Parametersof Chilika Lake after opening of New Mouth Near Gabakunda, Orissa, India. Academy of management and Information Technology, Orissa India.

[40]. Raibole, M. And Singh, Y. P. (2011). Impact of Physico-Chemical Parameters On Microbial Diversity: Seasonal Study. Current World Environment, 6(1), 71-76.

[41]. Rimonson., A.M (2008) An Assessment of Portable Water Supply in Jema local Government Area of Kaduna State , A Bachelor of Science Research Project Report, Department of Geography, Amhadu Bello University, Zaria, Nigeria

[42]. Sahni, K. And Yadav, S.(2012). Seasonal Variations in Physico-Chemical Parameters of Bharawas Pond, Rewari, Haryana. Asian J. Exp. Sci., 26(1); 61-64

[43]. Schofield ,J., Merniman I. (2008). Impact of Intensive Diary Farming Activities on River Quality. Wiley Interscience Journal; water and environment Journal.

[44]. Sharma, C., D.K. Deka and K.G. Bhattacharyya, (1995). Bacteriological quality of a few Entrapped Water Rources in and around Guwahati. Journal of Environmental Protection, 15: 850-852.

[45]. Shmidt, MA and Esa RS (2008) Drilled Wells and Groundwater in the Precambian Crystalline Bedrock of Finland, Water Research Institute, Helsinki, Finland, pp 57

[46]. Smith, A.H., E.O. Lingas and M. Rahman,(2000). Contamination of drinking-water by arsenic in Bangladesh: A public health emergency. Bull. World Health Organ., 78: 1093-1093 
[47]. Turgeon, S., J. M Rodriguez, M. Theriault and P. Levallois,(2004). Perception of Drinking Water in the Duebec City Region (Canada). The Influence of Water Quality and Consumer Location in the Distribution System. Journal of Environmental. Management. 70: 363-373.

[48]. Venkatesharaju K.; Ravikumar. P., Somashekar. R. K., And Prakash. K. L. (2010). Physico Chemical And Bacteriological Investigation on the River Cauvery of Kollegal Stretch in Karnataka. Kathmandu University Journal of Science, Engineering and Technology 6 (I): 50-59

[49]. Udom , G, I , Esu , E.O and Ekwere , SJ (2004) Quality Status of Calabar Municipality, South Eastern Nigeria , Global Journal of Pure and Applied Science" In Imoke D E (2012) The Effect of Aquifer Characteristics on Groundwater Yield and Quality in Calabar South, Nigeria , A PhD Dissertation, Department of Geography and regional Planning, University of Calabar, Nigeria

[50]. US Environmental protection Agency (2004) Taking Stock of Year Water System; A Simple Asset Inventory for Small Drinking Water System. Office of water $(4606 \mathrm{~m})$ EPA.816-k-03-002. www.epa/gov/safewater

[51]. WHO, (2002). The world health report 2002-Reducing Risks. Promoting Healthy Life World Health

[52]. WHO, (2004). Rolling Revision of the WHO Guidelines for Drinking-Water Quality, Draft for Review and Comments. Nitrates and Nitrites in Drinking-Water, World Health Organization. (WHO/SDE/WSH/04.08/56).

[53]. WHO,(2004). Guideline for Drinking Water Quality. $3^{\text {rd }}$ Edn., World Health Organization, Geneva, pp: 104. 